\title{
How Autonomous are Public Corporations in Hong Kong? The Case of the Airport Authority
}

\author{
Anthony B. L. Cheung
}

Published online: 7 September 2006

(C) Springer Science + Business Media, LLC 2006

\begin{abstract}
This article examines the degree of autonomy of Hong Kong's Airport Authority (AA). Traditionally, airport management in Hong Kong was the responsibility of the government's Civil Aviation Department. The AA was established in 1995 to manage the new international airport at Chek Lap Kok which opened in 1998. It was expected to run as a commercial enterprise but, because of its strategic importance, there was concern that it should not become an independent empire detached from government control. As a hybrid type of organization, the AA has moved steadily towards full commercialization. The government has also put its privatization on the agenda. Its transformation may have some implications for the redefinition of the future autonomy boundaries of public corporations in Hong Kong.
\end{abstract}

Keywords Autonomy-Integration - Corporatization · Privatization · Airport Authority $\cdot$ Accountability $\cdot$ Regulatory controls $\cdot$ Price cap

\section{Introduction}

The development of public corporations, statutory authorities and non-statutory public bodies in the period immediately after the Second World War was originally interpreted as a way of disguising the growth of "big government" (Barker, 1982), or as a means of "bureaucratic load-shedding to prevent political or administrative 'overload' at the centre" (Hood, 1982). Since the late 1980s, however, the formation of non-departmental executive bodies and unincorporated statutory authorities out of core government departments - collectively known as "agencies" (Pollitt, Bathgate, Caulfield, Smullen, \& Talbot, 2001) — and the setting up of incorporated statutory authorities and government owned enterprises - known as "corporatization"- - have become typical processes of redefining core government-agency relationships in the

\footnotetext{
A. B. L. Cheung $(\square)$

Department of Public and Social Administration,

City University of Hong Kong,

Kowloon, Hong Kong, China
} 
name of "new public management" (Lane, 2000, 2005). This in turn has given rise to legally and operationally autonomous structures for the sake of improving efficiency and effectiveness (Thynne \& Wettenhall, 2004). Following the typology used by Verhoest, Peters, Bouckaert \& Verschuere (2004: 110), the transition to full autonomy from a core government organization ultimately settles in an externally autonomous public organization with a private law legal personality.

Against this background, the setting up of an Airport Authority (AA) in Hong Kong could easily be regarded as attesting to such organizational development. Traditionally, airport management in Hong Kong was the responsibility of the government's Civil Aviation Department when the airport was located at Kai Tak. The AA was set up in the mid-1990s originally as a provisional airport authority to manage the construction of the new international airport at Chek Lap Kok, which formally opened in 1998. Initially, the then British colonial administration preferred to model the AA on the Mass Transit Railway Corporation (MTRC), and to make it a fully commercial enterprise. However, there were objections both from China and from within Hong Kong. The Chinese government, always suspicious of any British conspiracy in the run-up to the transfer of sovereignty in 1997, was concerned that the AA would become an independent empire with control over such strategic operations as airport management. Local views were also not positive about a prospective airport corporation free from government intervention for fear that it might become too powerful, with undue impact on economic life and the well-being of businesses, large and small. The final AA is a hybrid with the nomenclature of an "authority" even though it has, since the opening of the new airport, moved steadily towards full commercialization and for all practical purposes has operated as a public corporation.

The history of the AA reflects institutional attempts to embrace both agency autonomy and government control. As Verhoest, et al. (2004: 109) point out, if one wants to know the level of autonomy of a public agency, not only must the decisionmaking competencies on managerial and policy matters of the agency be analyzed, one must also consider to what extent the government can constrain the use of these competencies by structural, financial, legal and interventional means. So just how autonomous as a public corporation is the AA?

Autonomy can be conceptualized at two different levels: in terms of core government-corporation relationships and in terms of government-society relationships. All of Hong Kong's public corporations have been formed for the purpose of extending quasi-government. This has been at a time of significant growth in the provision of public goods and services in response to rising social and economic demands, rather than as socially embedded organizations to delimit state control as part of "de-governmentalization". Thus, the first set of relationships seems more pertinent to this discussion. To the extent that public corporations are viewed as policy instruments, the Hong Kong government has always been concerned with the integration of these bodies within the overall public sector configuration and with effective policy coordination. In the colonial past, the government retained extensive veto and residual powers over the operation of public corporations, so that the integration-autonomy equation was always tipped to the side of government. This legacy continued after Hong Kong reverted to Chinese sovereignty in 1997. On the other hand, public corporations, being designed to follow the market logic (or 
"prudent commercial principles" as government likes to call it), tend to regard autonomy in their management and modus operandi as crucial, so tensions with government officials have been witnessed from time to time.

In this article, the degree of autonomy of the AA is examined within such a fused context, made more complicated by the recent inclusion of the privatization of the AA on the government agenda. At the same time, the AA is venturing into new business opportunities by developing a local logistics centre and seeking to take over the management of neighbouring airports in the Pearl River Delta region of China. This regionalization policy will see the AA's relationship with the government gradually transformed. Together with the recent proposed merger of the two railway corporations, ${ }^{1}$ and the likely partial if not full privatization of the new railway conglomerate, the AA's transformation may also have some implications for the redefinition of autonomy boundaries of public corporations in the future.

\section{The Airport Authority: Formation and Operation}

\section{Building the New Airport: The Political Disputes}

In October 1989, then Governor, David Wilson, announced in his policy address an ambitious plan to construct a new international airport at Chek Lap Kok as part of an overall port and airport development strategy (PADS). The project was launched to bolster confidence in Hong Kong's future which had been badly affected by the June 4 Tiananmen crackdown on democracy in China. ${ }^{2}$ In April 1990, the government set up the Provisional Airport Authority (PAA) under the Provisional Airport Authority Ordinance, with a mandate to plan, design and construct the new airport. This move signaled its intention to use a non-departmental corporate body to manage the future airport. At the time of the announcement of the new airport project, Britain vowed to go ahead with its plans regardless of whether it would receive China's approval. However, such approval was essential to enable the Hong Kong government to attract private sector funding for the project. Britain eventually had to enter into negotiations with China, culminating in the signing of a Memorandum of Understanding (MoU) in September 1991. The MoU gave China an almost equal say in the project through a new airport committee established under the Sino-British Joint Liaison Group, the body responsible for overseeing the political transition to Chinese sovereignty. The MoU specifically required China's approval for major airport-related franchises, contracts or guarantees for debts straddling 30 June 1997 (Memorandum of Understanding, para. C (i), 1991).

The major area of contention between the Chinese and British governments related to the financing arrangements, with the former worrying that the British administration might use up Hong Kong's fiscal reserves and unduly favor British companies in the award of airport-related contracts. Under the MoU (para. D),

\footnotetext{
${ }^{1}$ The two railway corporations are the MTRC and the Kowloon-Canton Railway Corporation (KCRC).

${ }^{2}$ As some have pointed out, the British interest in maintaining confidence in Hong Kong's future was far from altruistic. As the largest source of private foreign investment in the city, Britain was acting in part to protect the massive investment of British companies (Bennett, 1995: 87).
} 
Britain agreed not to incur debt repayable after 30 June 1997 in excess of HK\$5 billion without the Chinese government's consent. In November 1994, the airport committee of the Joint Liaison Group signed an Agreed Minute on the financing of the new airport and airport railway, whereby the amount of private sector borrowing was capped at HK $\$ 23$ billion, as opposed to the initial British proposal of HK\$69 billion. The airport committee was also given the role of monitoring and controlling the cost of the project. In June 1995, the airport committee reached further agreement on the terms of the Financial Support Agreement for the future Airport Authority and on the air cargo franchises.

\section{Establishment of the AA and Operational Performance}

In July 1995, the Airport Authority Ordinance was enacted by the Legislative Council. It came into effect on 1 December that year, when government advances of HK $\$ 36.6$ billion were converted into equity upon the establishment of the new Authority. The Financial Support Agreement and the Land Grant were also signed between the government and the AA. On 2 July 1998, the new international airport was opened by China's then president, Jiang Zemin, which was followed by an overnight relocation from Kai Tak on 5 July.

In June 2000, the AA presented its 1999/2000 annual report to the Legislative Council, in which it reported a consolidated operating profit of HK\$291 million (Hong Kong Airport Authority, 2004b). Its consolidated loss had been reduced to HK\$168 million after the deduction of finance costs and minority interests, compared with HK\$388 million for the nine-month period since the opening of the airport in 1998. In 2000-01, the AA reported for the first time a consolidated net profit of HK\$71 million, which grew to HK\$236 million in the following year (Hong Kong Airport Authority, 2004b).

Meanwhile, the AA started planning for the expansion of facilities and the diversification of its business, including a marine cargo terminal and logistics centres. In October 2001, the AA unveiled The HKIA Master Plan 2020, outlining plans to further develop the international airport to meet its ultimate design capacity of 87 million passengers and nine million tones of cargo annually by 2020 (Hong Kong Airport Authority, 2004b). ${ }^{3}$ In August 2003, the AA and the government entered into a joint venture with the consortium led by Dragages et Travaux Publics (HK) Limited to design, construct and operate the AsiaWorld Expo, an exhibition and event venue at the airport to be opened by the end of 2005 (Hong Kong Airport Authority, 2005: 51). In its 2001-2002 annual report, the AA expressed its confidence in meeting the target should the government decide to arrange for its privatization (Hong Kong Airport Authority, 2002). In August 2003, the Financial Secretary, Henry Tang, announced a plan to partially privatize the AA, as part of the government's privatization program following the stock market listing of the MTRC in October 2000. On 22 November 2004, the government's Economic Development and Labour Bureau released a Consultation Document on Partial Privatization of the Airport Authority for public consultation (Economic Development and Labour Bureau, 2004).

\footnotetext{
${ }^{3}$ In 2005, the AA started its study for the Master Plan 2025.
} 
A summary of the key financial and operational performance indicators of the AA since 1998-1999 is provided in Table 1.

\section{Corporatization Debates: Autonomy, Accountability and the Scope of Business}

\section{Airport Corporation vs Airport Authority Debate, 1994}

How much autonomy the AA should enjoy was the key issue during the debates on its corporatization (out of the previous PAA) in 1994. The original Airport Corporation White Bill gazetted by the government in January 1994 envisaged the setting up of an Airport Corporation in line with the MTRC model. ${ }^{4}$ It would be wholly governmentowned, but would be allowed greater freedom to operate in a more commercial and independent manner than any government department. A financial analyst suspected at the time that "the corporatization of the new airport governing body was also paving the way for its possible privatization some way down the line". ${ }^{5}$ Much of the controversy about the Bill centered on three main issues:

- Whether the airport governing body should be an Authority or a Corporation. Clause 6 (i) of the MoU (1991) provided for the setting up of an "Airport Authority" and that "the Airport Authority Ordinance will be modeled as far as possible on the Mass Transit Railway Corporation Ordinance". By substituting "Corporation" for "Authority", even though the MTRC model was still adhered to, the Bill created suspicions on the part of the Chinese government that the future corporation would be subject to limited government control and might become "an independent empire". 6

- Whether the board membership should be enlarged to include legislators. There was considerable demand from elected legislators that some of them be appointed to the board to help monitor its work and enhance its accountability, especially in light of revelations that the PAA had given a HK\$5.5 million golden handshake to its former chief executive, Richard Allen, in order to terminate his contract (Cheung, 1993a: 5, 1993b: 3).

- Whether the airport body's accounts should be subject to the Director of Audit's scrutiny. The then Director of Audit, Brian Jenny, had previously complained about the difficulty of access to PAA accounts and now expressed the view that he should have access to the books and records of public corporations. He was backed by major political parties (Lee, Li \& Law, 1993: 1).

\footnotetext{
${ }^{4}$ A White Bill is a draft bill issued for public consultation before the final bill (Blue Bill) is tabled at the legislature for debate and enactment.

${ }^{5}$ Peter Churchouse, a principal at Morgan Stanley Asia, in the South China Morning Post (Porter, 1994: 4).

${ }^{6}$ A local delegate to China's National People's Congress (NPC), Cheng Yiu-tong, criticized the change of name, which he said would raise Chinese concern that the intention was to form an independent empire. Fellow NPC delegate Kan Fook-yee, also said it was better to give the government greater control over the new airport rather than putting it under a corporate system that could allow it to run out of control. The Chairman of the New Airport Consultative Committee set up under the $1991 \mathrm{MoU}$, Wong Po-yan, said he would prefer the new body to retain the title of 'Authority' (Cheung, 1994: 1).
} 
Table 1 Key performance indicators of the AA.

\begin{tabular}{llllllll}
\hline Indicators & $\begin{array}{l}1998- \\
1999^{\mathrm{a}}\end{array}$ & $\begin{array}{l}1999- \\
2000\end{array}$ & $\begin{array}{l}2000- \\
2001\end{array}$ & $\begin{array}{l}2001- \\
2002\end{array}$ & $\begin{array}{l}2002- \\
2003\end{array}$ & $\begin{array}{l}2003- \\
2004\end{array}$ & $\begin{array}{l}2004- \\
2005\end{array}$ \\
\hline $\begin{array}{l}\text { Return on net } \\
\text { assets (\%) }\end{array}$ & -1.1 & -0.5 & 0.2 & 0.6 & 1.4 & 1.0 & 4.0 \\
$\begin{array}{l}\text { Debt/equity ratio } \\
\text { Total passengers } \\
\text { (millions) }\end{array}$ & 0.21 & 0.21 & 0.21 & 0.23 & 0.21 & 0.21 & 0.33 \\
$\begin{array}{l}\text { Cargo tonnages } \\
\text { (millions) }\end{array}$ & 1.2 & 30.9 & 33.8 & 33.1 & 34.2 & 27.7 & 38.3 \\
$\begin{array}{l}\text { Aircraft movements } \\
\text { Airaft men }\end{array}$ & 122,000 & 169,000 & 186,000 & 198,000 & 212,000 & 190,000 & 242,000 \\
\hline
\end{tabular}

Performance in 2003-2004 was affected by the outbreak of SARS (severe acute respiratory syndrome) during the first half of 2003.

${ }^{\text {a }}$ Period from 6 July 1998 to 31 March 1999

Source: Hong Kong Airport Authority, 2005: 96.

\section{Airport Authority Ordinance 1995}

The final version of the bill, a product of negotiations between the British and Chinese governments at the joint Airport Committee, accepted the reinstatement of the Airport Authority title to alleviate Chinese government suspicions. The new Airport Authority Bill also restricted the AA to undertake only "airport-related activities" (instead of "such activities as the Governor may... permit") and imposed the requirement that the Financial Secretary's consent had to be sought before land granted by government under the airport construction program could be sold or any borrowings could be made. The proposal to have statutory inclusion of legislators on the AA board was not accepted. Instead of strengthening the Director of Audit's jurisdiction over the AA, a new audit committee was to be appointed to provide an audit function independent of the AA management.

Comparing the Airport Corporation White Bill of January 1994 with the Airport Authority Bill of May 1995, there seems to be little material difference with the exception of the previously mentioned changes. Even without the "Corporation" title, for all practical purposes, the AA was intended to function as a public corporation with autonomy to manage its assets and to set charges subject to government's directions and consent. The chairman and eight to fifteen members of the AA board are to be appointed by the Governor/Chief Executive who has to approve the board's appointee as chief executive officer (CEO). In common with other public corporations, the Governor/Chief Executive retains ultimate appointment, regulatory and financial controls over the operations of the AA. These powers cover a whole range of areas: land use, investment, payment of dividends out of profits, reserve funds, borrowings, and scale of airport charges. The Governor/Chief Executive may also obtain information from the AA at any time. However, despite the legal limitations imposed on the AA's powers, and the various residual powers still vested in the government, in practice the AA can be (and has indeed been) allowed by government to operate in a rather autonomous manner in order to enable it to achieve an efficient use of its assets and to adhere to prudent commercial principles. Thus, while the framework of control is there, the scope of autonomy can still expand or be constrained depending on 
whether government prefers the AA to operate more autonomously for business and other reasons. Even in 1995, it seemed evident that government was contemplating the AA's full commercialization and eventual privatization, subject to some overall strategic controls. The post-1997 administration has continued such policy thinking. Indeed, in order to enable the AA to venture further into the business market, its scope of permitted activities was widened in 2002 .

\section{Extension of Airport-Related Business}

In March 2002, the Chief Executive sought the Legislative Council's support for a draft Airport Authority (Permitted Airport-Related Activities) Order to enable the AA to undertake airport-related activities in order to enhance the status of Hong Kong as a centre of international and regional aviation and, in particular, to collaborate with nearby airports on the mainland. These activities included: entering into alliances and other cooperation arrangements with other airports, investing in other airport governing bodies and other airports outside Hong Kong, providing facilities or services (whether in Hong Kong or elsewhere) for land and sea transport between the airport and other places, and developing logistics facilities to enhance the traffic flow through the Hong Kong International Airport (Economic Services Bureau, 2002a). Questions were raised as to the meaning of "airport-related activities", in reply to which the government quoted the definition used by the former Secretary for Economic Services in moving the second reading of the Airport Authority Bill on 24 May 1995:

[B]y "airport-related", we mean that the Authority should only undertake activities which are essential or conducive to the efficient operation of the airport or which are related to the development and running of an airport, for example, the development of hotels, freight forwarding facilities, offices or other commercial and retail premises. We do not envisage that the Authority will undertake activities which are not normally undertaken by airports in other territories (as quoted in Economic Services Bureau, 2002b).

To address legislators' concern, further conditions were subsequently added (Economic Services Bureau, 2002c):

- the AA can only engage in activities which it can lawfully undertake in Hong Kong and which are expedient for or conducive to the promotion or maintenance of Hong Kong's status as a centre of international and regional aviation, or the competitiveness of the airport;

- the AA can operate carriage and logistics services only if it is not practicable for any other person to provide the service and that it is requisite or expedient for AA to provide the service;

- the AA is required to seek the prior approval of the Financial Secretary for investment in permitted airport-related activities in an airport outside Hong Kong involving an amount of consideration exceeding $2.5 \%$ of the AA's issued share capital of HK\$36,648 million (i.e., HK\$916.2 million);

- the acquisition of shares, loans or other stocks, and debentures is restricted to airports in any other part of the People's Republic of China only; and 
- the AA's other activities regarding alliances, partnerships, joint ventures and consultancy and management services are restricted to the development, maintenance or operation of an airport outside Hong Kong.

These requirements were to prevent the AA from unduly exploiting its monopolistic advantage vis-à-vis other commercial enterprises and over-extending its scope of business beyond its core business and outside Hong Kong. Under these terms, the AA has sought to expand its airport-related business in mainland China. In April 2005, it concluded a deal to invest close to HK\$1.9 billion in Hangzhou's Xiaoshan International Airport (equivalent to $35 \%$ of the latter's shares) (Lo, 2005).

\section{Proposal on Partial Privatization: Expansion Flexibility vs Strategic Controls}

In August 2003, the government announced a plan to commence work on the proposed privatization of the AA. The rationale for privatization was essentially twofold: to help strengthen the AA's market discipline in the running of the airport for greater efficiency and more commercial opportunities; and to introduce an additional quality stock to Hong Kong's financial market (Economic Development and Labour Bureau, 2004). This was an almost identical rationale to that of the MTRC's privatization in 2000. To prepare for the privatization, the government took steps to enhance the AA's capital structure by reducing its equity capital and hence optimizing its debt-to-equity ratio. ${ }^{7}$

A new company was to be formed under the Companies Ordinance with all the assets, properties, rights and obligations of the AA which would be vested in it by statute. After the formation of the new company, the government would dispose part of its shares in it through an initial public offer (IPO) and list it on the Hong Kong stock exchange. But the government would continue to be the majority shareholder in the foreseeable future and retain adequate powers over the new company in order to safeguard public interests in addition to its role as regulator. An IPO was preferred partly because of its success in the MTRC's partial privatization and partly because it has been commonly adopted in airport privatizations elsewhere. In addition, the government's financial advisers, UBS Investment Bank, concluded that other options-including sale to strategic investors, securitization, the issue of exchangeable bonds, and sale to the Exchange Fund-were less effective in conferring ownership of the airport to members of the public (Economic Development and Labour Bureau and Financial Services and the Treasury Bureau, 2004a: 2-3).

\section{Major Concerns}

The government had earlier consulted the Legislative Council's Panel on Economic Services in March 2004 about the partial privatization proposal (Economic

\footnotetext{
7 This was done in June 2004 in order to enable AA to have a debt-to-equity ratio about 1:2 instead of current ratio of about 1:4. However, the debt-to-equity ratio reported by the AA in its 2004-2005 annual report was still only 1:3 (or 0.33 ) (see Table 1 above).
} 
Development and Labour Bureau and Financial Services and the Treasury Bureau, 2004b). The key concerns expressed by legislators were:

- the impact on the AA employees and staff of airport franchisees and contractors;

- the possibility of the AA abusing its monopolistic power (given its holding on 1,255 ha of land on the airport island) and becoming "an independent kingdom" after privatization (a similar concern to that expressed in the 1994 corporatization debates);

- whether the AA would focus solely on maximizing returns to shareholders after privatization, at the expense of airport users, which might result in high airport charges that could hurt the Hong Kong airport's competitiveness;

- the risk of the AA engaging in anti-competitive practices after privatization;

- how service standards and efficiency at the airport could be ensured after privatization; and

- whether the government's arm's length control would make the privatized AA less effective in negotiations and cooperation with regional airports, thus weakening the hub status of Hong Kong.

The Economic Development and Labour Bureau admitted in its public consultation document (2004: 14) that some members of the airport community and labor organizations were concerned about the potential negative impact of privatization on their companies or the welfare of workers at the airport, and expected that the new airport company would become more profit-oriented and exploit them whenever possible. ${ }^{8}$ Airlines were concerned that the new airport company might set high airport charges and thus suggested that the airport should adopt a "single till" approach. This concern was understandable at the time of consultation because, until 2004-2005, the AA recorded rates of return on equity of well below $2 \%$, far lower than what would be considered reasonable from a commercial perspective (Economic Development and Labour Bureau, 2004: 6). This created pressure for airport charges to be increased prior to the initial public offer so as to demonstrate to potential investors its ability to achieve a commercial return within a reasonable time frame. However, with the growth in both passenger traffic and cargo throughput in 2004-2005, the AA achieved a triple increase in profit, from HK\$386 million in 2003-2004 to HK\$1410 million (Hong Kong Airport Authority, 2005:96). In 2004, airport charges accounted for about 45\% of the AA's total revenue (Economic Development and Labour Bureau, 2004: 7). The percentage has since fallen to $41 \%$ in 2005 (Hong Kong Airport Authority 2005: 61). The government is still undecided on the level of aeronautical charges, putting the pros and cons of fee increases as set out in Table 2.

The International Air Transport Association (IATA), which represents airline operators' interests, has openly expressed its reservation on the AA's privatization. IATA's Director General and CEO, Giovanni Bisignani (2005), claimed that US $\$ 40$ billion was paid annually to airlines' monopoly suppliers - namely, airports and air

\footnotetext{
${ }^{8}$ The public consultation exercise ended on 31 May 2005 with over 60 submissions received by the Economic Development and Labour Bureau. However, the Bureau has not released the details of those submissions. The sense of urgency about airport privatization seems to have subsided because of recent improvement in the government's fiscal situation due to the rebound of the economy.
} 
Table 2 Arguments for and against increases in airport charges.

\begin{tabular}{ll}
\hline For & Against \\
\hline 'User pays' principle & $\begin{array}{c}\text { Airport is a public infrastructure and } \\
\text { a long-term investment } \\
\text { High charges hurt the airport's competitiveness }\end{array}$ \\
$\begin{array}{l}\text { Airport charges account for less than 4\% } \\
\begin{array}{l}\text { of airlines' operating cost } \\
\text { Airlines respond to demand }\end{array}\end{array}$ \\
\hline
\end{tabular}

Source: Economic Development and Labour Bureau, 2004.

navigation service providers - representing $10 \%$ of their operating costs. Airlines are therefore very concerned that airport privatizations might lead to higher airport charges and thus greater costs to them. According to Bisignani (2005):

Already Hong Kong has the highest charges to airlines in this region [i.e., Asia] next to Japan and the mainland of China. Any increase in charges will disadvantage Hong Kong compared to its neighbouring airports. A successful privatization should generate efficiencies to allow for reduced costs.

There is also concern that the AA would be privileged over other developers or other private enterprises, given the huge amount of land it holds and its status as the operator of the airport, which could give rise to unfair competition or anticompetitive practices. The government's objective is to strike the right balance between the need to provide the new airport company with maximum expansion flexibility and the need for adequate controls in order to protect the strategic importance of the facility and ensure fair charges for users.

\section{Proposed Regulatory Controls and Safeguards}

According to the government's consultation document (Economic Development and Labour Bureau, 2004), the new AA company will still be subject to various regulatory controls and safeguards, no less vigorous than in the current regime. Actually, some of the new arrangements have been proposed to ensure that there is sufficient control and accountability, mostly in the areas of corporate control and economic regulation. These enable the government to appoint additional board members to represent government in addition to the number of directors it appoints as the majority shareholder (a similar arrangement to that for the partially privatized MTRC). The government is also charged with approving the capital investment plan and preventing shareholding from falling into foreigners' hands or being dominated by any single private investor (hence the residency requirement for the majority of shareholders and the $10 \%$ limit on a single shareholder, again in line with the arrangements for the MTRC).

In order to ensure that the AA would not become an uncontrollable monopoly, and that government would not lose its strategic control over such a vital facility as a major international airport, it is also proposed to empower government to take over the new company in case of default or under an emergency situation (with compensation to it under specified circumstances). This takeover provision is seen to be the ultimate safeguard of the public interest. Government would also be 
empowered to impose financial penalties on the AA company for breaches of relevant laws and licensing conditions, and to suspend or revoke its aerodrome licence in justifiable cases. The existing restrictions on the range of airport-related activities that the AA may conduct will be retained. However, in view of the new company's corporate status as a listed company, government may consider replacing the existing prior approval by the Financial Secretary for the AA's commercial activity by a new legislative provision that will empower it to direct the AA company to divest an investment or to desist from undertaking an activity found outside the range of permitted activities.

The existing AA ordinance has not specified the framework for air charges, except for the general requirement that such a charging scheme should be approved in draft by the Chief Executive-in-Council. The current proposal provides for a transparent regulatory framework to be established for the determination of airport charges based on the "user pays" principle, to allow the AA company a reasonable return on its investment, and to provide incentives for enhancing efficiency and increasing capacity to cater for demand. Only airport charges (that is, landing, parking and terminal building charges) paid by airlines will be regulated. The AA company will be allowed to negotiate with airlines' representatives on the level of airport charges every 3 years or as the need arises, against a set of pre-agreed parameters. In the event of disagreement, either government or a governmentappointed independent panel will be empowered to adjudicate on the reasonable level of airport charges. The AA company will also be required to draw up a set of service standards, on the basis of which a financial reward and penalty system will be devised to link actual service standards to the level of airport charges.

\section{Evaluating the Autonomy of the AA}

The government's objective is to see the AA further expand its revenues and business within the more flexible structure of a private company, to enable it to have better access to the capital market, and to let the market test its efficiency and profitability. It is also clearly the AA's corporate wish to be given greater flexibility to extend into other air-related activities whether in Hong Kong or outside (in particular, neighboring airports and cities in the Pearl River Delta Region of China with which the AA has already cultivated good relations). For example, the AA has set up air cargo consolidation centres in the Pearl River Delta Region, with the first phase coming into operation in October 2003 in the Futian Free Trade Zone in Shenzhen (Hong Kong Airport Authority, 2004a: 45).

Newberry (1999: 17-24) has suggested that government policy towards public network utilities must address three levels of questions, namely:

(a) Property rights - how to ensure that the large amounts of specific sunk capital are financed and, especially, how property rights in this capital are to be defined, allocated, and protected;

(b) Structure- how to ensure the right structure of the utility is in place, both vertically and horizontally, which entails issues of market structure, access, coordination, entry and expansion; and

(c) Efficiency - how to meet the classic concerns of regulation and pricing. 
In the AA case, government ownership presently ensures the solution on property rights. The second question seems less relevant because of the AA's natural monopoly status, at least in relation to its airport activities in Hong Kong; however, coordination and expansion are still important issues. The efficiency question is arguably the most critical in the debate on privatization. According to Newberry (1999: 23), the British experience shows that the failure to develop a viable regulatory compact for private ownership has often made public ownership irresistible, illustrating the inherent tensions between autonomy and control in these organizational forms at the margin of government.

Using the framework of Verhoest et al. (2004: 107-109), the degree of autonomy of the AA is at best qualified or indeterminate, as illustrated in Table 3.

There remains an innate political concern, in both government and the legislature, that a privatized AA may become too detached from the public interest and care only for maximizing its shareholders' interests at the expense of government as well as airport users. Some worry that with its huge land holding and monopolistic control of a most strategic public facility, and with its capacity to expand into airport-related areas, the AA could develop into an independent kingdom of its own. This worry was expressed during the AA's corporatization in 1994 and 1995 and has now been rearticulated in the current discussion on partial privatization. Economic concerns over the price cap and prevention of anti-competitive practices are similar to those aired in most airport privatizations elsewhere.

The proposed new corporate structure and regulatory framework to be applied to the AA after partial privatization reflect the attempt to strike a balance between corporate flexibility for the AA and government controls and accountability. In terms of ownership and corporate controls, while government ownership will be diluted, government will continue to be the majority shareholder, at least in the foreseeable future. No single shareholder, other than the government, will be allowed to own more than $10 \%$ of total voting rights. Government will appoint a minority number of directors to represent the public interest in addition to any rights it may have as a shareholder. As the major shareholder, government will also presumably appoint the chairman of the board. What remains unknown, of course, is the arrangement after the government surrenders its majority shareholding. When the new airport was opened in 1998, the government appointed Billy Lam, the former director of the New Airport Project Coordination Office and an administrative officer, as CEO of the AA so as to ensure a close government connection. It was only after 2001 that an outsider, David Pang, was recruited to replace Lam who went on to become managing director of the Urban Renewal Authority. Both the previous and current AA chairmen (Wong Po-yan and Victor Fung) are considered safe hands by the bureaucracy and have sat on various important boards and committees; they are also close friends of former Chief Executive Tung Chee-hwa who appointed them.

In terms of accountability, the AA company will have to be accountable to the government in its capacity as both the investor and regulator. Various financial controls have been built into the proposed privatized framework. In terms of regulatory regime, there will be controls over pricing, investment, service performance, and scope of services. On the price cap, after consultation with the airlines the government will prescribe a price regulatory mechanism for the setting of price caps for airport charges by the AA company for 3 to 5 years, taking into 
Table 3 Autonomy and control in the case of the AA.

Dimensions of autonomy of the AA

Autonomy as having own decision- making competencies:

Managerial autonomy-maximum. The AA may decide itself upon all aspects of management including procedures and transactions, and the use of resources.

Policy autonomy-high to maximum. The AA may decide upon which policy instruments to use and output norms within the objectives and effect norms set by government. It can determine prices and investment plans within government- agreed perimeters. The AA is authorized to issue general regulations for managing the airport and dealing with airlines and other users (high strategic policy autonomy).

Autonomy as being shielded from government constraints on actual decision-making:

Structural autonomy-high. The AA chairman is appointed and evaluated by the supervisory board in which the representatives of government have a majority vote. These representatives could be required to resign by government at any time. At present, the CEO of the AA can be appointed and dismissed by the board only with the prior approval of the government.

Financial autonomy-maximum. The AA is financed exclusively through airport-related and other commercial income from sources other than government contribution and is self-sufficient.

Legal autonomy-high to maximum. At present, the AA has a legal personality under public law and is created by an act of the legislature. After privatization, the AA company will have a legal personality under private law.

Interventional autonomy-low to high. The AA has some general reporting requirements (for example, financial, service performance) to government against specified norms, but is not subject to government audit. (Instead, it has its own external audit and an Audit Committee). There is a threat of sanctions/penalties or intervention by government in case of default or non-compliance with requirements.
Dimensions of control by government

Control as the ex ante limitation of decision-making competencies by rules and a priori approval procedures:

The scope of airport-related business to be defined by government. The AA is prohibited from engaging in anti-competitive activities. Civil Aviation Department regulates the AA's aviation activities and safety standards, and enforces compliance.

Government has control over land use and requires prior approval of investment, borrowings, and retention of reserve funds. Government sets the regulatory framework for the determination of airport charges.

Control as the constraints on the actual use of the decision-making competencies delegated to the agency:

Control by influencing the AA's decisions through accountability lines towards the AA chairman or through the board. Government has representatives of the public interest on the board in addition to members to exercise its majority shareholder rights.

Control by influencing the AA's investment and pricing decisions (through economic regulation and the price cap). The AA is required to submit annual accounts, and a five-yearly business plan and financial plan to government. Government may direct the AA to declare and pay a dividend out of profits.

Control by changing the legislative instrument that gives the AA its legal personality and authority.

Control by influencing the AA's decisions on reporting requirements, evaluating and audit provisions against externally set goals and norms and by the threat of sanctions or direct interventions, such as takeover of assets in case of default or under emergency, and by giving directions to the AA in the public interest. Government has to approve the appointment of auditors. It may also intervene in price setting if the AA fails to reach agreement with airlines.

Source: Framework adapted from Verhoest et al. (2004: Tables 2 and 3). 
account projected costs, revenues and capital expenditure relating to regulated activities. There is also provision for government intervention through direct action or a government-appointed independent panel. On the return on investment, the government will cap the return from regulated activities. However, because the AA company is free to adopt any target return for the non-regulated activities, its overall return could be "above the cap". On service performance, the government will require a set of service standards with a financial reward and penalty system linking actual performance to price levels. On the scope of business, the government will approve the range of permissible airport-related businesses. In addition, there will be some residual government controls, whereby the government will have the power to give directions, to obtain information, to impose financial penalties, to suspend or revoke the aerodrome license, and to take over the company's assets in case of default or under an emergency situation.

\section{Concluding Remarks}

On the face of the current government proposal, the new AA after partial privatization is unlikely to gain many new powers or unchecked freedoms. The government will continue to maintain overall control through majority ownership, regulation and those residual powers which are presently exercised over the AA. The change in operation may be less substantive than expected, for two main reasons. First, the AA created under the Airport Authority Ordinance of 1995 has already been given almost full corporate flexibility with the mandate to operate according to prudent commercial principles no different from that of a private company. The only restrictions are those involving pricing, use of land, financing and borrowings where prior government consent or formal approval is required. At present, the government already keeps an arm's length relationship with the AA so far as its commercial discussions and negotiations with third parties are concerned, including those with other airports. So what partial privatization will add are the inclusion of private ownership and the listing of the AA on the stock exchange, hence bringing into the system external discipline from the market. Second, existing controls and safeguards geared towards preventing the AA from abusing its monopolistic power or not acting according to government-defined public interests will remain intact after privatization, including the power of suspension and revocation of the aerodrome license and of takeover by the government. Other regulatory and monitoring mechanisms will persist, such as the price cap, safety and security requirements. The audit committee will also presumably continue.

As the devil very often is in the details, how these controls and safeguards may operate, of course, depends on the specific statutory provisions governing the future AA company. Political influence, whether from legislators or other stakeholders, will still be brought to bear upon the privatized AA through the government as majority shareholder and economic regulator. The real test of accountability and autonomy will come when the government gives up its majority shareholding and the AA company becomes fully private. Arguably, as in the case of the British Airport Authority, the government could still retain a golden share, reserving the right to intervene. It is entirely plausible that the AA's existing autonomy in fee-setting, subject to prior consent of its charging scheme, may be replaced by a prescribed 
price cap formula in order for it to gain greater operational freedom as a limited company rather than as a public corporation. The government remains vague as to the kind of economic regulatory regime to be introduced for a privatized AA. This, however, is potentially the most controversial aspect, judging by the responses of the airline industry and other major users. It may make or unmake the case for privatization. In any case, the present kind of fused "autonomy-control" mode of organization will persist for good administrative and political reasons.

Acknowledgment The author is most grateful to Lo Oi-yu, senior research assistant of the Governance in Asia Research Centre, City University of Hong Kong, for the research assistance provided in the preparation of this article.

\section{References}

Barker, A. (Ed.). 1982. Quangos in Britain: Government and the Networks of Public Policy-Making. London: Macmillan.

Bennett, M. S. 1995. Financing the chek Lap Kok new airport: A case study in amending the Sino-British joint declaration on the question of Hong Kong. Journal of Chinese Law, 9(1): 77-92.

Bisignani, G. 2005. Speech at aerospace forum asia. Hong Kong, 15 April.

Cheung, D. 1993a. Legislators pledge close scrutiny of airport bill. South China Morning Post, 22 February, Hong Kong.

Cheung, D. 1993b. Call for PAA to act more openly. South China Morning Post, 7 June, Hong Kong.

Cheung, D. 1994. Surprise proposals trigger warning. South China Morning Post, 4 January, Hong Kong.

Economic Development and Labour Bureau. 2004. Consultation Document on Partial Privatization of the Airport Authority. November, Hong Kong.

Economic Development and Labour Bureau and Financial Services and the Treasury Bureau. 2004a. Privatization of Airport Authority. Paper for discussion at Legislative Council Panel on Economic Services on 23 February 2004, CB(1)1017/03-04(05), February, Hong Kong.

Economic Development and Labour Bureau and Financial Services and the Treasury Bureau. $2004 \mathrm{~b}$. Response to Questions raised on 23 February 2004 Relating to Privatization of the Airport Authority. Paper for discussion at Legislative Council Panel on Economic Services on 2 March 2004, CB(1) 1154/03-04(01), February, Hong Kong.

Economic Services Bureau. 2002a. Proposed Airport Authority (Permitted Airport-Related Activities) Order. Informational Paper for Legislative Council Panel on Economic Services, CB(1)1310/01-02 (03), March, Hong Kong.

Economic Services Bureau. 2002b. The meaning of 'airport-related activities' in the Airport Authority Ordinance (Cap. 48). Paper for Legislative Council Panel on Economic Services, CB(1)1514/01-02, March, Hong Kong.

Economic Services Bureau. 2002c. Proposed Airport Authority (Permitted Airport Related Activities) Order. Informational Paper for Legislative Council Panel on Economic Services, CB(1)2033/0102 (03), June, Hong Kong.

Hong Kong Airport Authority. 2002. 2001-02 Annual Report. Hong Kong: Airport Authority.

Hong Kong Airport Authority. 2004a. 2003-04 Annual Report. Hong Kong: Airport Authority.

Hong Kong Airport Authority. 2004b. Hong Kong International Airport-about us-key dates and events. Accessed on web http://www.hongkongairport.com in November.

Hong Kong Airport Authority. 2005. 2004-05 Annual Report. Hong Kong: Airport Authority.

Hood, C. 1982. Government bodies and government growth. In Barker, A. (Ed.). Quangos in Britain: Government and the Networks of Public Policy-Making. London: Macmillan.

Lane, J.-E. 2000. New Public Management. London: Routledge.

Lane, J.-E. 2005. Public administration and public management: The principal-agent perspective. London: Routledge.

Lee, C., Li, P., Law, C. 1993. Audit chief seeks access to books of airport body. South China Morning Post, 1 August, Hong Kong.

Lo, J. 2005. Hangzhou airport deal fixed. South China Morning Post, Business Post, 26 April, Hong Kong. Memorandum of Understanding Concerning the Construction of the New Airport in Hong Kong and 
Related Questions. 1991. Signed between the heads of the British and Chinese governments in Beijing, September 3.

Newberry, D. M. 1999. Privatization, restructuring, and regulation of network utilities. Cambridge, Mass: MIT.

Pollitt, C., Bathgate, K., Caulfield, J., Smullen, A., \& Talbot, C. 2001. Agency fever? Analysis of an international policy fashion. Journal of Contemporary Policy Analysis, 3(3): 271-290.

Porter, B. 1994. Airport Bill 'sensible but useless'. South China Morning Post, 5 January, Hong Kong.

Thynne, I. \& Wettenhall, R. 2004. Public management and organizational autonomy: The continuing relevance of significant earlier knowledge. International Review of Administrative Sciences, 70(4): 609-621.

Verhoest, K. B., Peters, G., Bouckaert, G., \& Verschuere, B. 2004. The study of organizational autonomy: A conceptual review. Public Administration and Development, 24(2): 101-118. 